\title{
ЕКСПЕРИМЕНТАЛЬНЕ ОБГРУНТУВАННЯ ВИБОРУ СУПОЗИТОРНОЇ ОСНОВИ ЕКСТЕМПОРАЛЬНИХ ПЕСАРІЇВ ДЛЯ ПІДГОТОВКИ ДО ПОЛОГІВ
}

\author{
Г.М. Мельник, Т.Г. Ярних, І.В. Герасимова
}

\author{
Національний фармацевтичний університет, м. Харків, Україна
}

\begin{abstract}
Метою роботи стало проведення фізико-хімічних та фармако-технологічних досліджень із вибору раціональної супозиторної основи при створенні екстемпоральних песаріїв (вагінальних супозиторіїв) із гіалуроновою кислотою та СО -екстрактами алое, календули й зеленого чаю, призначених для підготовки пологових шляхів і зменшення ризику виникнення розривів м'яких тканин при пологах.

Матеріали та методи. Об'єктом дослідження були зразки песаріїв, виготовлені методом виливання із використанням у якості активних фармацевтичних інгредієнтів гіалуронової кислоти, $\mathrm{CO}_{2}$-екстрактів алое, календули та зеленого чаю. Зразки песаріїв готували із використанням таких супозиторних основ: вітепсол Н-15, масло какао, твердий жир кондитерський та масло какао у сплаві із емульсійним воском у співвідношенні 95:5. Під час досліджень визначали однорідність, середню масу, рН, температуру плавлення, час повної деформації, час розпадання та мікробіологічну чистоту песаріїв за методиками ДФу. Біофармацевтичні дослідження проводили використовуючи загально прийнятий метод «агарових пластин».
\end{abstract}

Результати. На підставі фізико-хімічних та фармако-технологічних досліджень обрано раціональну супозиторну основу масло какао : емульсійний віск (95:5). Вивчено основні показники якості зразків песаріїв (вагінальних супозиторіїв): органолептичні характеристики (колір, поверхня, запах, консистенція), середню масу, температуру плавлення, час повної деформації, час розпадання, рН, які відповідають вимогам ДФУ. У результаті визначення мікробіологічної чистоти встановлено, що загальне число життєздатних мікроорганізмів (ТАМС) не перевищує $10^{2} \mathrm{KУО/мл,} \mathrm{загальне} \mathrm{число} \mathrm{дріжджових} \mathrm{та}$ плісеневих грибів (ТҮMC) не перевищує 101. Отримані результати випробування відповідають вимогам ДФу до песаріїв за показником «Мікробіологічна чистота». Біофармацевтичними дослідженнями доведено, що найбільший ступінь вивільнення діючих речовин відбувається із песаріїв, виготовлених на основі масло какао : емульсійний віск (95:5) у порівнянні зі зразками, виготовленими на основі вітепсолу H-15.

Висновки. Проведено фізико-хімічні та фармако-технологічні дослідження із вибору супозиторної основи при створенні екстемпоральних песаріїв (вагінальних супозиторіїв) із гіалуроновою кислотю та СО -екстрактами алое, календули і зеленого чаю. Обрано раціональну основу масло какао : емульсійний віск (95:5). Вивчено фізико-хімічні та фармако-технологічні показники песаріїв: однорідність, температуру плавлення, час повної деформації, час розпадання, $р Н$, середню масу, які відповідають вимогам статті ДФу 2.0 «Супозиторії та песарії, виготовлені в умовах аптек».

Ключові слова: екстемпоральні песарї̈; супозиторна основа; температура плавлення; час повної деформації, час розпадання, мікробіологічна чистота.

Вступ. Незважаючи на значні досягнення світової медицини, яка враховує відомі фізіологічні механізми і багатовіковий досвід акту народження, пологи й на сьогодні залишаються процесом непередбачуваним. Звісно, усі необхідні заходи щодо підготовки пологових шляхів спрямовані на те, щоб пологи не завдавали травм ні матері, ні дитині. За даними сучасної літератури, близько 20 \% пологів через природні пологові шляхи ускладняються травмами м'яких тканин пологового каналу [1-3]. I, якщо пологовий біль має властивість швидко забуватися, то пологовий травматизм - це те, що жінка не лише довго пам'ятає, але й те, що у ряді випадків призводить до тривалої втрати нею працездатності, а іноді й до інвалідизації [1].

Значне розтягнення пологових шляхів матері нерідко призводить до їх пошкодження.
Серед травм нижніх відділів пологового каналу розрізняють пошкодження тканин шийки матки, піхви, вульви і промежини [4-6]. Раціональна підготовка пологових шляхів із урахуванням особливостей гістологічної будови вагінальної стінки повинна передбачати застосування препаратів, спрямованих на підвищення тонусу еластичних і колагенових волокон, що стимулюють глікогеноутворення, а також підтримку захисного середовища, тобто місцевого імунітету м'яких тканин пологових шляхів [7-10].

Як зарубіжні, так й вітчизняні автори, серед провідних причин пошкодження м'яких тканин пологових шляхів виділяють: їх анатомо-функціональні зміни під час гестації, особливості ведення пологів, а також 
недостатню еластичність тканин або їх порушення.

Тому, важливим завданням сучасної медицини та фармації $\epsilon$ застосування вагінальних лікарських засобів, спрямованих на збільшення еластичності м'яких тканин пологових шляхів та їх супротиву до травматизації. Нажаль на сьогодні, відсутні лікарські засоби подібної дії, а ті препарати, що представлені на фармацевтичному ринку України із подібною активністю відносяться до дієтичних добавок, зокрема вагінальні супозиторії «Ревітакса» (Хелп С.А., Греція) [1113].

Отже, розробка нових лікарських засобів у даній лікарській формі з метою підготовки пологових шляхів жінки перед пологами та зменшення ризику виникнення розривів м'яких тканин $€$ актуальним завданням сучасної фармацевтичної та медичної практики.

Відомо, що для створення екстемпоральних песаріїв (вагінальних супозиторіїв) потрібно обирати основу, рекомендовану ДФУ. Під час обгрунтування складу і технології екстемпоральних песаріїв слід ураховувати природу та кількість основи, допоміжні речовини

(ПАР, структуроутворювачі тощо), фізико-хімічні властивості активних фармацевтичних інгредієнтів (АФI) i допоміжних речовин, технологічні операції й апаратуру, використовувану для приготування лікарської форми.

Варто зауважити, що терапевтичний ефект супозиторіїв, як лікарської форми, залежить не лише від АФІ, але й від раціонально підібраної основи, враховуючи фізико-хімічні властивості АФІ, що впливає на забезпечення необхідних структурномеханічних властивостей препарату, та $\epsilon$ однією із характеристик, що визначає стійкість зв'язно-дисперсних систем.

Супозиторна основа володіє певними фізико-хімічними властивостями та чинить істотний вплив на біофармацевтичні характеристики препарату, точність дозування та однорідність розподілу АФІ тощо [9].

Фармацевтичною промисловістю на сьогоднішній день запропоновано широкий асортимент гідрофобних і гідрофільних супозиторних основ, які відрізняються за своїми фізико-хімічними властивостями.

Нами попередньо було проведено їх аналіз, на підставі якого для подальших експериментальних досліджень було обрано: масло какао, вітепсол Н-15, твердий кондитерський жир та сплав масло-какао : емульсійний віск (95: 5) [14].

Метою роботи стало проведення фізикохімічних та фармако-технологічних досліджень із вибору супозиторної основи при створенні песаріїв (вагінальних супозиторіїв) із гіалуроновою кислотою та $\mathrm{CO}_{2}$-екстрактами алое, календули й зеленого чаю, призначених для підготовки пологових шляхів і зменшення ризику виникнення розривів м'яких тканин при пологах.

Матеріали та методи дослідження. Методологія дослідження. Методологічний підхід до розробки складу супозиторної основи екстемпоральних песаріїв базувався на пошуковому та дослідницькому етапах.

Узагалі, фармацевтична розробка супозиторіїв грунтується на вимогах нормативної документації до такої лікарської форми, має відповідати передбачуваній науковій меті, а планування i проведення досліджень бути конкретними для кожного препарату.

На сьогодні у світі загальну структуру досліджень із розробки лікарських засобів стандартизовано у Рекомендації ICH Q8 із фармацевтичної розробки [15].

У ДФУ 1.0 у статті «Лікарські засоби для ректального застосування» наведено загальні вимоги до супозиторіїв. У ДФУ 2.0 у розділі «Екстемпоральні лікарські засоби» наведено статтю «Супозиторії та песарії, виготовлені в умовах аптек», яка регламентує показники їх якості.

Технологія

екстемпоральних супозиторіїв / песаріїв має забезпечувати їх якість відповідно до вимог ДФУ та інших чинних нормативних документів [16-18]. Технологію підбирають із урахуванням фізико-хімічних властивостей АФІ та допоміжних речовин, їх прописаної маси, сумісності, дисперсної системи, що має утворитися, методу виготовлення супозиторіїв.

Алгоритм теоретичного обґрунтування складу і технології екстемпоральних супозиторіїв / песаріїв наведено на рис. 1 .

При створенні екстемпоральних песаріїв враховували, що загальна структура досліджень із фармацевтичної розробки має бути спрямована на отримання лікарського засобу відповідної якості із заданими функціональними характеристиками. 
Алгоритм розробки базувався на декількох складових: на вимогах до якості супозиторіїв / песаріїв, на результатах власних експериментальних досліджень і наукової літератури, на теоретичному аналізі асортименту допоміжних речовин і науковому підході до їх застосування.

Завданнями даних досліджень став вибір супозиторної основи на підставі вивчення фізико-хімічних та фармако-технологічних показників досліджуваних композицій супозиторіїв із гіалуроновою кислотою та рослинними екстрактами.

Об'єктом дослідження були зразки песаріїв, виготовлені методом виливання із використанням в якості АФІ гіалуронової кислоти, $\mathrm{CO}_{2}$-екстрактів алое, календули та зеленого чаю.

\begin{tabular}{|c|}
\hline $\begin{array}{l}\text { Алгоритм теоретичного обгрунтування складу і технології } \\
\text { екстемпоральних прописів супозиторіїв / песаріїв }\end{array}$ \\
\hline 1. Розрахування кількості АФІ згідно із прописом рецепта \\
\hline $\begin{array}{l}\text { 2. Обгрунтування вибору та розрахування кількості допоміжних } \\
\text { речовин відповідно до фізико-хімічних властивостей АФІ, способу } \\
\text { прописування та методу виготовлення супозиторіїв / песаріїв }\end{array}$ \\
\hline $\begin{array}{l}\text { 3. З’ясування можливих фізико-хімічних несумісностей АФІ та } \\
\text { допоміжних речовин }\end{array}$ \\
\hline $\begin{array}{l}\text { 4. Обгрунтування порядку введення АФІ у основу відповідно до } \\
\text { правил (настанова «Вимоги до виготовлення нестерильних лікарських } \\
\text { засобів»). Визначення технологічних стадій (підготовка основи, введення } \\
\text { АФІ у основу, дозування та формування) }\end{array}$ \\
\hline $\begin{array}{l}\text { 5. Вибір пакування у залежності від фізико-хімічних властивостей } \\
\text { інгредієнтів, маркування }\end{array}$ \\
\hline 6. Внутрішньоаптечний контроль якості \\
\hline
\end{tabular}

Рисунок 1. Обгрунтування складу і технології екстемпоральних прописів супозиторіїв/песаріїв.

Гіалуронова кислота (натрію гіалуронат низькомолекулярний (sodium hyaluronate) (Ph Eur 2.0, P. 1472)

CAS:9067-32-7, Мм 0,1 МДа

Гіалуронова кислота (ГК) - це аніонний, несульфатований глікозаміноглікан, широко розподілений по сполучній, епітеліальній та нервовій тканинах. Є одним із основних компонентів позаклітинного середовища, а саме позаклітинного матриксу. За рахунок здатності зв'язувати воду у співвідношенні 1000:1, надає тканинам пружності, еластичності та супротиву до травматизації.

Розчинність: легко розчинна у холодній воді, нерозчинна у органічних розчинниках

$\mathrm{CO}_{2}$-екстракт алое

CAS:85507-69-3

INCI: $\mathrm{CO}_{2}$ Aloe Barbadensis Leaf Extract

Склад: глікозиди, смолисті речовини, ефірна олія, вітамін Е, С, В, бета-каротин, близько 20 амінокислот, ефірні масла, мікроелементи

Опис: масляниста рідина злегка жовтуватого відтінку $45^{\circ} \mathrm{C}$

Розчинність: в олії при температурі 35-

\section{$\mathrm{CO}_{2}$-екстракт календули}

CAS:70892-20-5 Extract

INCI: $\mathrm{CO}_{2}$ Calendula officinalis Flower

Склад: каротиноїди, терпеноїди (туйон, $\alpha$-пінен, кубенен, кадинен, гермакрен, аромадендрен, кадинен, муурол, лоліелід), жирні кислоти, токофероли, фітостерини, флавоноїди, сапоніни, саліцилова кислота.

Опис: рідка масляниста маса від темнокармінового до оранжево-коричневого кольору з характерним своєрідним запахом.

Розчинність: в олії при температурі 35$45^{\circ} \mathrm{C}$.

$\mathrm{CO}_{2}$-екстракт зеленого чаю 
CAS:84650-60-2

INCI: $\mathrm{CO}_{2}$ Camellia sinensis Extract

Склад: кофеїн, терпеноїди, жирні кислоти

Опис: масляниста рідина злегка жовтуватого відтінку та специфічного запаху олії чайного дерева

Розчинність: в олії при температурі 35$45^{\circ} \mathrm{C}$

Масло какао (Oleum Cacao) (DAB 10.1 Nachtrag 1992, Монографія Kakaobutter (Cacao oleum) - тверда жовтого кольору крихка 3 приємним запахом шоколаду маса. Температура плавлення $-31-36^{\circ} \mathrm{C}$. Кислотне число - 1,67; йодне число - 35,16. У хімічному відношенні масло какао це суміш гліцеридів складних ефірів гліцерину і вищих жирних кислот.

Вітепсол H-15 (Witepsol H-15) (ЄФ, 2005, 5 вид., спільна монографія гідрофобних допоміжних речовин) - біла, тверда, крихка, легкоплавка при температурі тіла маса без смаку та запаху. У хімічному відношенні - це суміш тригліцеридів насичених жирних кислот і 1 \% моно-, дигліцеридів тих самих кислот. Температура плавлення $-33,5-35,5^{\circ} \mathrm{C}$. Температура затвердіння $-32,5-34,5^{\circ} \mathrm{C}$; йодне число - не більше 3,0 ; кислотне число - не більше 0,2 .

Твердий кондитерський жир (ДФУ 2.0, T. 2, с. 608) - суміш моно-, ди-, тригліцеридів жирних кислот, які можуть бути одержані етерифікацією жирних кислот природного походження гліцерином або переетерифікацією природніх жирів. Крихка воскоподібна маса від білого до світло-жовтого кольору, допускається сіруватий або жовтуватий відтінок із запахом, який $\epsilon$ характерним для жиру. Температура плавлення - не вища за $37{ }^{\circ} \mathrm{C}$, температура затвердіння - не нижча, ніж $30{ }^{\circ} \mathrm{C}$, кислотне число не більше 0,3. Гідроксильне число - не більше 20. Йодне число - не більше 3,0 . Перекисне число - не більше 3,0.

Крім супозиторних основ, у дослідженнях використовували такі допоміжні речовини: вода очищена, полісорбат-80 та віск емульсійний.

Вода очищена (ДФУ 2.0, Т. 2, с. 129) безбарвна прозора рідина без запаху і смаку, $\mathrm{pH}$ 5,0-6,8. Використовується як універсальний розчинник для АФІ та допоміжних речовин.

Полісорбат-80 (Твін-80) (ТУ 6-14-938$79)$ - полісорбат, моноолеат, неіоногенна ПАР. Одержують із сорбіту та жирних кислот оливкового масла хімічним способом. Являє собою рідку, маслянисту і злегка в'язку речовину. Колір може бути від світло-жовтого до яскраво-бурштинового. Запах не сильний, характерний. Розчинний в оліях рослинного i тваринного походження, воді. Також він добре розчиняється в ізопропиловому та етиловому спирті, бензолі. у мінеральних маслах розчиняється.

Віск емульсійний Polawax NF (ТУ У 24.122942814.018-2001) - с синтетичний емульгатор другого роду (в/о), являє собою суміш калієвих солей ефірів фосфорної кислоти 3 вищими жирними спиртами. Однорідна маса від білого до світло-кремового кольору у вигляді лусок або стружок без сторонніх домішок.

Однорідність песаріїв визначали згідно ДФУ, на повздовжньому розрізі не повинно спостерігатись вкраплень, допускається наявність повітряного стрижня лійкоподібної форми.

Середню масу визначали відповідно ДФУ, зважуючи 20 одиниць песаріїв.

Температуру плавлення зразків проводили за допомогою відкритого капілярного методу (ДФУ 2.0, п. 2.2.15, с. 63).

Час повної деформації визначали відповідно ДФУ 2.0, п. 2.9.22, с. 446.

Час розпадання проводили згідно ДФУ 2.0 , п. 2.9.2, с. 398. Випробування на розпадання досліджуваних песаріїв були проведені 3 використанням пристрою PHARMA TEST (модель PTS 3E) для визначення розпадання супозиторіїв і песаріїв. Зразки препарату поміщали у перфорований кошик, який поміщали на водяну баню і підігрівали до $37^{\circ} \mathrm{C}$; зразки оберталися на $180^{\circ} \mathrm{C}$ кожні 10 хв.

Вивчення $p H$ зразків проводили відповідно ДФУ 2.2, п. 2.2.3, с. 51.

Для проведення біофармацевтичного дослідження використовували 2 \% агаровий гель, теплий розчин якого розливали у чашки Петрі. Для визначення ступеню дифузії діючих речовин в якості взаємодіючих із ними індикаторів використовували стибію (III) хлорид і кислоту фосфорно-молібденову.

Стибію (III) хлорид слугував реактивом для якісного визначення каротиноїдів, що містяться в $\mathrm{CO}_{2}$-екстракті календули, при їх взаємодії утворюється синє або синьо-зелене забарвлення. Що стосується кислоти фосфорно-молібденової, то даний реактив вступає у взаємодію із токоферолами, які $€$ біологічно-активними речовинами $\mathrm{CO}_{2}$ екстракту алое. У результаті хімічної реакції токоферолів та вказаного реактиву 
утворюється зелене забарвлення. Наведені індикатори вводили до складу агарового гелю. У чашках Петрі у сформованому агаровому гелі за допомогою циліндру діаметром 8 мм вирізали по 3 лунки, у які поміщали досліджувані зразки. Готові системи термостатували при температурі $37{ }^{\circ} \mathrm{C}$ упродовж 12 год., при цьому вимірювали діаметр забарвлених зон навколо кожної лунки щогодини.

Випробування на мікробіологічну чистоту проводили згідно ДФУ 2.3, п. 5.1.4. Дослідження проводили в лабораторії біохімії мікроорганізмів і поживних середовищ інституту мікробіології та імунології ім. I. I. Мечникова АМН України, під керівництвом к. біол. н. Осолодченко Т. П.

Статистичну обробку результатів досліджень проводили відповідно до методик ДФУ 2.3, п. 5.3 із використанням персональних комп'ютерів при застосуванні табличного процесора Microsoft Excel у складі Microsoft Office та пакету прикладних програм Statistica.

Результати дослідження. У попередніх дослідженнях нами було обрано в якості АФІ гіалуронову кислоту, що володіє зволожувальною, репаративною та протизапальною дією та $\mathrm{CO}_{2}$-екстракти алое, календули і зеленого чаю, які в комплексі проявляють зволожуючу, репаративну, протизапальну дію та збільшують еластичність i супротив до механічного пошкодження м'яких тканин [19].

Виходячи із цього, можна передбачити, що майбутній екстемпоральний лікарський засіб у вигляді песаріїв, до складу якого лікарі прописують гіалуронову кислоту $(0,005$ г) та $\mathrm{CO}_{2}$-екстракти алое $(0,06$ г), зеленого чаю $(0,002$ г) і календули $(0,06$ г), дасть змогу знизити пологову травматизацію м'яких тканин під час пологів.

Для експериментального обгрунтування вибору супозиторних основ досліджували вітепсол Н 15, твердий жир кондитерський, масло какао, масло какао : емульсійний віск у співвідношенні 95:5. Для оцінки виготовлених зразків досліджували однорідність, температуру плавлення, час повної деформації, $\mathrm{pH}, \quad$ середню масу, біофармацевтичні характеристики та мікробіологічну чистоту. Вивчення усіх показників проводили згідно із ДФУ [16-17].

У ході дослідження були виготовлені зразки песаріїв методом виливання, враховуючи фізико-хімічні властивості усіх AФI.
Гіалуронову кислоту розчиняли у мінімальній кількості води, супозиторну основу розплавляли та вводили до неї почергово $\mathrm{CO}_{2}$-екстракти алое, календули та зеленого чаю і все ретельно перемішували. Виготовлення супозиторної маси проводили при температурі $40,0 \pm 2,0^{\circ} \mathrm{C}$.

Враховуючи те, що усі основи, окрім твердого жиру кондитерського, володіють певними емульгуючими властивостями, додавання емульгатору не $\epsilon$ доцільним. У випадку із твердим жиром кондитерським, вводили емульгуючий агент - полісорбат-80.

Технологія песаріїв методом виливання в умовах аптек складається із таких стадій: підготовка супозиторної форми, підготовка основи, підготовка АФІ та допоміжних речовин, змішування та розлив супозиторної маси у форми, охолодження, виймання, пакування, оформлення.

При виготовленні песаріїв методом виливання їх маса залежить від величини гнізда форми, щільності АФІ та основи. У нашому випадку кількість АФІ складає менше $5 \%$, тобто об'єм, який вони займають $є$ незначним i y розрахунках нами не враховувався.

Для виготовлення песаріїв використовували супозиторну форму торгової марки «Промвіт» із масою 2,6 г - за жировою основою. Форма виготовлена із матеріалу фторпласт Ф-4 (тефлон) (ТУ 6-05-810-88) із числом гнізд - 20.

Форму змащували мильним спиртом, використовуючи мінімальну кількість цієї речовини, щоб забезпечити тонкий шар на стінках форми. Надлишок речовини для змащування призводить до деформації песаріїв, при недостатній кількості - можливо їх прилипання до форми.

Підготовка основи залежить від типу основи. Згідно фармакопеї США та ДФУ масло какао використовують як у методі виливання, так і викачування. Але при використанні масла какао у методі виливання необхідно дотримуватися температурного режиму плавлення i не допускати перегріву, для попередження утворення модифікації, яка має низьку температуру плавлення, внаслідок чого отримані песарії будуть розплавлятися при кімнатній температурі. Для усунення цього факту ми використовували емульсійний віск, який підвищував температуру плавлення отриманих песаріїв.

Отриману супозиторну масу розливали при температурі $40,0 \pm 2,0 \quad{ }^{\circ} \mathrm{C} . \quad$ Розлив 
проводили, починаючи із одного кінця форми, i заповнювали по черзі кожне супозиторне гніздо, уникаючи утворення повітряних пустот у песаріях. При наповненні супозиторних гнізд заливали невеликий надлишок супозиторної маси. Процес розливу супозиторної маси у гнізда не переривали до повного заповнення форми.

Заповнену форму залишали стояти при кімнатній температурі протягом 15-30 хвилин, а потім поміщали у холодильник на 15-20 хвилин (на допускаючи заморожування). Після застигання та охолодження песарії виймали із форми і загортали у вощані капсули (або запечатували у контурну упаковку із полімерних матеріалів, комбінованих матеріалів із алюмінієвою фольгою).

Аналогічно отримували зразки на інших основах та використовували для досліджень.

Таблиця 1

Органолептичні характеристики песаріїв в залежності від носія

\begin{tabular}{|c|c|c|c|c|c|c|}
\hline Основа & Колір & Поверхня & Запах & $\begin{array}{c}\text { Консистен- } \\
\text { ція } \\
\end{array}$ & Однорідність & $\begin{array}{c}\text { Небажані } \\
\text { зміни } \\
\end{array}$ \\
\hline $\begin{array}{l}\text { Вітепсол } \\
\text { Н15 }\end{array}$ & Білий & Гладка & $\begin{array}{c}\text { Специфічний } \\
\text { запах масла } \\
\text { какао та } \\
\text { екстракту } \\
\text { зеленого чаю }\end{array}$ & Тверда & $\begin{array}{c}\text { Однорідні, в } \\
\text { деяких } \\
\text { випадках } \\
\text { наявний } \\
\text { повітряний } \\
\text { стрижень }\end{array}$ & $\begin{array}{c}\text { Відсутні } \\
\text { видимі } \\
\text { зміни }\end{array}$ \\
\hline Масло какао & $\begin{array}{c}\text { Білий із } \\
\text { жовтим } \\
\text { відтінком }\end{array}$ & Гладка & $\begin{array}{c}\text { Специфічний } \\
\text { запах масла } \\
\text { какао та } \\
\text { екстракту } \\
\text { зеленого чаю }\end{array}$ & Тверда & $\begin{array}{c}\text { Однорідні, в } \\
\text { деяких } \\
\text { випадках } \\
\text { наявний } \\
\text { повітряний } \\
\text { стрижень } \\
\end{array}$ & $\begin{array}{c}\text { Спостеріга- } \\
\text { ється } \\
\text { незначна } \\
\text { деформація }\end{array}$ \\
\hline $\begin{array}{l}\text { Масло } \\
\text { какао: } \\
\text { емульсійни } \\
\text { й віск (95:5) }\end{array}$ & $\begin{array}{c}\text { Білий із } \\
\text { жовтим } \\
\text { відтінком }\end{array}$ & Гладка & $\begin{array}{c}\text { Специфічний } \\
\text { запах масла } \\
\text { какао та } \\
\text { екстракту } \\
\text { зеленого чаю }\end{array}$ & Тверда & $\begin{array}{c}\text { Однорідні, в } \\
\text { деяких } \\
\text { випадках } \\
\text { наявний } \\
\text { повітряний } \\
\text { стрижень } \\
\end{array}$ & $\begin{array}{c}\text { Відсутні } \\
\text { видимі } \\
\text { зміни }\end{array}$ \\
\hline $\begin{array}{l}\text { Твердий } \\
\text { жир } \\
\text { кондитер- } \\
\text { ський }\end{array}$ & Білий & Гладка & $\begin{array}{c}\text { Специфічний } \\
\text { запах масла } \\
\text { какао та } \\
\text { екстракту } \\
\text { зеленого чаю }\end{array}$ & Тверда & $\begin{array}{c}\text { В деяких } \\
\text { випадках } \\
\text { наявні } \\
\text { вкраплення }\end{array}$ & $\begin{array}{c}\text { Спостеріга- } \\
\text { ється } \\
\text { деформація }\end{array}$ \\
\hline
\end{tabular}

Визначення середньої маси супозиторіїв $(\mathrm{n}=\mathbf{2 0})$

\begin{tabular}{|l|c|}
\hline \multicolumn{1}{|c|}{ Основа } & Середня маса, г \\
\hline Вітепсол Н15 & $2,56 \pm 0,06$ \\
\hline Масло какао & $2,61 \pm 0,03$ \\
\hline Масло какао: емульсійний віск (95:5) & $2,58 \pm 0,05$ \\
\hline Твердий жир кондитерський & $2,50 \pm 0,10$ \\
\hline
\end{tabular}

Температура плавлення та час повної деформації супозиторіїв

Таблиця 3

\begin{tabular}{|l|c|c|}
\hline \multicolumn{1}{|c|}{ Основа } & $\begin{array}{c}\text { Температура плавлення, } \\
{ }^{\circ} \mathbf{C}\end{array}$ & Час повної деформації, хв \\
\hline Вітепсол Н-15 & $35,4 \pm 0,6$ & $7,5 \pm 0,2$ \\
\hline Масло какао & $33,5 \pm 0,5$ & $5,0 \pm 0,2$ \\
\hline $\begin{array}{l}\text { Масло какао: емульсійний віск } \\
\text { 95:5) }\end{array}$ & $35,7 \pm 0,5$ & $8,0 \pm 0,2$ \\
\hline Твердий жир кондитерський & $34,5 \pm 0,5$ & $5,2 \pm 0,1$ \\
\hline
\end{tabular}

Ступінь вивільнення біологічно-активних речовин із песарї̈в на основі вітепсолу Н-15 


\begin{tabular}{|l|l|l|l|l|l|l|l|l|l|l|l|l|}
\hline & $\begin{array}{l}\mathbf{1} \\
\text { год }\end{array}$ & $\begin{array}{l}\mathbf{2} \\
\text { год }\end{array}$ & $\begin{array}{l}\mathbf{3} \\
\text { год }\end{array}$ & $\begin{array}{l}\mathbf{4} \\
\text { год }\end{array}$ & $\begin{array}{l}\mathbf{5} \\
\text { год }\end{array}$ & $\begin{array}{l}\mathbf{6} \\
\text { год }\end{array}$ & $\begin{array}{l}\mathbf{7} \\
\text { год }\end{array}$ & $\begin{array}{l}\mathbf{8} \\
\text { год }\end{array}$ & $\begin{array}{l}\mathbf{9} \\
\text { год }\end{array}$ & $\begin{array}{l}\mathbf{1 0} \\
\text { год }\end{array}$ & $\begin{array}{l}\mathbf{1 1} \\
\text { год }\end{array}$ & $\begin{array}{l}\mathbf{1 2} \\
\text { год }\end{array}$ \\
\hline Каротиноїди & 9,1 & 9,4 & 9,8 & 10,4 & 11,3 & 11,9 & 12,2 & 124, & 12,5 & 12,6 & 12,6 & 12,6 \\
\hline Токофероли & 9,4 & 9,9 & 10,7 & 11,3 & 12,1 & 12,8 & 13,5 & 14,1 & 14,7 & 14,9 & 15 & 15 \\
\hline
\end{tabular}

Таблиця 5

Ступінь вивільнення біологічно-активних речовин із песаріїв на основі масло какао : емульсійний віск (95:5)

\begin{tabular}{|l|l|l|l|l|l|l|l|l|l|l|l|l|}
\hline Група БАР & \multicolumn{10}{c|}{ Діаметр забарвленої зони, мм } \\
\cline { 2 - 12 } & $\begin{array}{l}\mathbf{1} \\
\text { год }\end{array}$ & $\begin{array}{l}\mathbf{3} \\
\text { год }\end{array}$ & $\begin{array}{l}\mathbf{4} \\
\text { год }\end{array}$ & $\begin{array}{l}\mathbf{5} \\
\text { год }\end{array}$ & $\begin{array}{l}\mathbf{6} \\
\text { год }\end{array}$ & $\begin{array}{l}\mathbf{7} \\
\text { год }\end{array}$ & $\begin{array}{l}\mathbf{8} \\
\text { год }\end{array}$ & $\begin{array}{l}\mathbf{9} \\
\text { год }\end{array}$ & $\begin{array}{l}\mathbf{1 0} \\
\text { год }\end{array}$ & $\begin{array}{l}\mathbf{1 1} \\
\text { год }\end{array}$ & $\begin{array}{l}\mathbf{1 2} \\
\text { год }\end{array}$ \\
\hline Каротиноїди & 10,1 & 11,9 & 12,8 & 13,7 & 14,5 & 15,2 & 15,9 & 16,5 & 16,9 & 17,4 & 17,8 & 18 \\
\hline Токофероли & 10,9 & 12,2 & 13,2 & 14,1 & 15,1 & 16,1 & 17 & 17,9 & 18,7 & 19,5 & 20,1 & 20,3 \\
\hline
\end{tabular}

Показники якості песаріїв на основі масло какао : емульсійний віск (95:5)

Таблиця 6

\begin{tabular}{|c|c|c|}
\hline Показник & Вимоги & Результати аналізу \\
\hline Опис & $\begin{array}{l}\text { Песарії жовтуватого кольору зі } \\
\text { специфічним запахом масла какао й } \\
\text { екстракту зеленого чаю }\end{array}$ & Відповідає \\
\hline Однорідність & $\begin{array}{l}\text { Мають бути однорідними, } \\
\text { дозволяється наявність повітряного } \\
\text { стрижня та/або лійкоподібної } \\
\text { заглибини }\end{array}$ & Відповідає \\
\hline Середня маса, г & $2,45-2,70$ & $2,58 \pm 0,06$ \\
\hline $\mathrm{pH}$ & $3,80-4,50$ & $4,10 \pm 0,05$ \\
\hline $\begin{array}{l}\text { Температура } \\
\text { плавлення }\end{array}$ & $(36,0 \pm 1,0){ }^{\circ} \mathrm{C}$ & $(35,7 \pm 0,5) \stackrel{\circ}{ } \mathrm{C}$ \\
\hline $\begin{array}{l}\text { Час повної } \\
\text { деформації, хв. }\end{array}$ & не більше 15 хв. & 8 хв. \\
\hline Час розпадання, хв. & не більше 30 хв. & $10 \mathrm{xB}$. \\
\hline $\begin{array}{l}\text { МБЧ:бактерії, гриби в } \\
1,0 \text { г }\end{array}$ & $\begin{array}{l}\text { не більше } 10^{2} \text { TAMC та } 10^{1} \text { TYMC } \\
\text { Відсутність Staphylococcus aureus, } \\
\text { Pseudomonas aeruginosa, Candida } \\
\text { albicans в } 1,0 \text { г }\end{array}$ & Відповідає \\
\hline
\end{tabular}

обговорення. Головне технологічне завдання при обгрунтуванні складу i технології екстемпоральних песаріїв полягає у тому, щоб уникнути розшарування супозиторної маси та максимально рівномірно розподілити АФІ у кожному супозиторію.

У таблиці 1 наведено результати вивчення органолептичних характеристик виготовлених зразків.

Проаналізувавши зовнішній вигляд одержаних песаріїв, можна зробити висновок, що зразки, виготовлені на супозиторних основах Вітепсол Н-15 та масло какао : емульсійний віск $(95: 5)$ не мали жодних небажаних проявів. При визначенні однорідності змішування було встановлено, що на повздовжньому зрізі маса $\epsilon$ однорідною, без вкраплень та у деяких песаріях спостерігалося утворення повітряного стрижня, що є припустимим. Проте, зразки, що містили масло какао та твердий жир, мали деформовану форму, що $є$ небажаним проявом, а також в деяких зразках, виготовлених на основі - твердий жир, спостерігалась наявність вкраплень.

Наступними показниками, за яким аналізували досліджувані зразки, стало визначення температури плавлення та часу повної деформації, а також середньої маси супозиторіїв. Згідно 3 вимогами ДФУ температуру плавлення визначали відкритим капілярним методом. Результати одержаних визначень наведені в таблиці 2 та 3.

Виходячи із одержаних результатів, середня маса супозиторіїв відповідає вимогам ДФУ, адже відхилення від середньої маси не перевищують допустимі норми - $\pm 5 \%$.

Стосовно визначення температури плавлення та часу повної деформації із даних таблиці 3 видно, що усі зразки відповідають 
вимогам ДФУ, проте песарії, виготовлені на основі Вітепсол Н-15 та масло какао : емульсійний віск (95:5) було обрано для подальших досліджень, адже вони продемонстрували більш високі показники якості на відміну від зразків, де в якості носія використовували масло какао в чистому вигляді та твердий жир кондитерський.

Такий підсумок досліджень можна зробити виходячи із того, що песарії, виготовлені на основах масло какао та твердий жир, за органолептичними показниками були неоднорідними та мали певну деформацію зразків. Крім того, відповідно до визначення фармакотехнологічних характеристик, зокрема, температури плавлення, саме зразки на основі Вітепсол Н-15 та масло какао : емульсійний віск (95:5) продемонстрували вказаний параметр максимально наближеним до температури тіла.

Наступним етапом роботи стало проведення біофармацевтичних досліджень із метою остаточного вибору раціонального носія песаріїв, які містять в якості АФІ гіалуронову кислоту та $\mathrm{CO}_{2}$-екстракти алое, календули та зеленого чаю.

Біофармацевтичні дослідження in vitro дозволяють вирішити ряд важливих питань, пов'язаних із встановленням найбільш важливих фармацевтичних факторів, що впливають на швидкість та повноту вивільнення АФІ із лікарської форми, що розробляється. В свою чергу, швидке та повне вивільнення діючих речовин, що визначається в дослідженнях in vitro, дає змогу вважати їх високу біодоступність in vivo.

При створенні супозиторіїв порівняльне вивчення біофармацевтичних показників експериментальних складів дозволяє визначити роль допоміжних речовин, зокрема супозиторних основ, в забезпеченні фармакотерапевтичних властивостей препаратів. Саме тому доцільним $\epsilon$ проведення порівняльного біофармацевтичного дослідження песаріїв, виготовлених на основі вітепсол Н-15 та масло какао : емульсійний віск (95:5), які були відібрані за результатами попередніх досліджень.

Результати досліджень наведені у таблицях 4 та 5.

Як видно із даних таблиць, ступінь вивільнення токоферолів переважає той самий показник стосовно каротиноїдів незалежно від того, яка супозиторна основа використовувалась для приготування песаріїв.
Але, варто зауважити, що зони дифузії як каротиноїдів, так і токоферолів із зразків виготовлених на основі масло какао : емульсійний віск (95:5) суттєво перевищують діаметр забарвлених зон вагінальних супозиторіїв, де в якості носія було використано вітепсол Н-15. Більше того, 3 табл. 4 видно, що вже після 9 години випробувань ступінь вивільнення біологічноактивних сполук майже не змінюється.

Виходячи із одержаних результатів необхідно зробити висновок стосовно остаточного вибору супозиторної основи на користь масло какао : емульсійний віск (95:5).

При оцінці зовнішнього вигляду та однорідності досліджуваних зразків екстемпоральних песаріїв (вагінальних супозиторіїв) одразу після їх виготовлення було встановлено, що вони мають дещо жовтуватий колір та специфічний запах масла какао й екстракту зеленого чаю. На поздовжньому зрізі зразків були відсутніми вкраплення, у деяких випадках спостерігалася наявність повітряного стрижня та / або лійкоподібної заглибини.

Показники $\mathrm{pH}$ водних розчинів зразків песаріїв знаходилися у межах від 3,80 до 4,50, що повністю відповідає нормальним значенням рН піхви жінки.

Результати визначення часу розпадання та МБЧ досліджуваних песаріїв наведено у таблиці 6.

Як видно із даних табл. 6, при вивченні часу розпадання зразків песаріїв вже через 10 хв. вони розділилися: розплавлені жирові компоненти зібрались на поверхні води, а розчинні компоненти розчинилися. Таким чином, зразки досліджуваних екстемпоральних песаріїв витримують випробування на розпадання та відповідають вимогам ДФУ, згідно із якими песарії на жировій основі мають розпадатися не пізніше, ніж за 30 хв.

у результаті визначення мікробіологічної чистоти встановлено, що загальне число життєздатних мікроорганізмів (ТАMC) не перевищує $10^{2}$ КУО/мл, загальне число дріжджових та плісеневих грибів (ТYMC) не перевищує 101. Отримані результати випробування відповідають вимогам ДФУ до песаріїв за показником «Мікробіологічна чистота».

Перспективним напрямом подальших досліджень $\epsilon$ розробка технологічної інструкції на виготовлення песаріїв із гіалуроновою кислотою та $\mathrm{CO}_{2}$-екстрактами 
алое, календули й зеленого чаю із метою їх впровадження у роботу аптек.

\section{Висновки}

1. Проведено фізико-хімічні та фармакотехнологічні дослідження із вибору супозиторної основи при створенні екстемпоральних песарї̈в (вагінальних супозиторіїв) із гіалуроновою кислотою та фітокомплексом $\mathrm{CO}_{2}$-екстрактів алое,

\section{Література}

1. Jansson M.H., Franzén K., Hiyoshi, A. et al. Risk factors for perineal and vaginal tears in primiparous women - the prospective POPRACT-cohort study. BMC Pregnancy Childbirth. 2020. № 20. P. 749.

2. Merriam A.A., Ananth C.V., Wright J.D., Siddiq Z., D'Alton M.E., Friedman A.M. Trends in operative vaginal delivery, 2005-2013: a population-based study. BJOG. 2017. № 124(9). P. 1365-1372.

3. Abraham de Jesús-García, Sergio Paredes-Solís, Geovani Valtierra-Gil et al. Associations with perineal trauma during childbirth at home and in health facilities in indigenous municipalities in southern Mexico: a cross-sectional cluster survey. BMC Pregnancy Childbirth. 2018. № 8. P. 198.

4. Bodner-Adler B., Kimberger O., Griebaum J., Husslein P., Bodner K. A ten-year study of midwife-led care at an Austrian tertiary care center: a retrospective analysis with special consideration of perineal trauma. BMC Pregnancy Childbirth. 2017. № 17(1). P. 357.

5. Ryan Goh Daryl, Goh Hasthika Ellepola. Perineal tears - A review. Australian Journal of General Practice. 2018. № 47(1-2). P. 35-38.

6. Vale de Castro Monteiro M, Pereira G.M., Aguiar R.A., Azevedo R.L. et al. Risk factors for severe obstetric perineal lacerations. Int Urogynecol J. 2016. № 27(1). P. 61-67.

7. Fodstad K., Staff A.C., Laine K. Sexual activity and dyspareunia the first year postpartum in relation to degree of perineal trauma. Int Urogynecol J. 2019. № 27(10). P. 1513-1523.

8. Sarah Krezić, Esved Krhan et al. Fabrication of rectal and vaginal suppositories using 3D printed moulds: the challenge of personalized therapy. IFMBE. 2019. № 73. P. 729-734.

9. Michael Barsky, Robert Kelley et al. Customized Pessary Fabrication Using Three-Dimensional Printing Technology. Obstet Gynecol. 2018. № 131(3). P. 493497.

10. Frigerio M., Manodoro S., Bernasconi D. et al. Incidence and risk factors of third- and fourth-degree perineal tears in a single Italian scenario. Eur J Obstet Gynecol Reprod Biol. 2018. № 221. P. 139-143. календули і зеленого чаю. Обрано раціональну основу масло какао : емульсійний віск (95:5).

2. Вивчено фізико-хімічні та фармакотехнологічні показники песаріїв: однорідність, температуру плавлення, час повної деформації, час розпадання, $\mathrm{pH}$, середню масу досліджуваних зразків песаріїв, які відповідають вимогам статті ДФУ 2.0 «Супозиторії та песарії, виготовлені в умовах аптек».

11. Webb S., Yates D., Manresa M. et al. Impact of subsequent birth and delivery mode for women with previous OASIS: systematic review and meta-analysis. Urogynecol J. 2017. № 28. P. 507-514.

12. Ginath S., Elyashiv O., Weiner E., et al. The optimal angle of the mediolateral episiotomy at crowning of the head during labor. Int Urogynecol J. 2017. № 28(12). P. 1795-99.

13. Shherbina N.A. et al. Racional'naja podgotovka rodovyh putej kak metod snizhenija travmatizma mjagkih tkanej v rodah. Reproduktivna endokrinologija. 2017. № 6(38). P. 91-95.

14. Melnyk Galyna, Yarnykh Tatyana, Herasymova Iryna. Analytical Review of the Modern Range of Suppository Bases. Sys Rev Pharm. 2020. № 11(4). P. 503-508.

15. Ляпунов М., Безугла О., Підпружников Ю. та ін. СТ-Н МОЗУ 42-3.0:2011 Лікарські засоби. Фармацевтична система якості (ICH Q8). Київ : MO3 України. 2011.

16. ДП «Український науковий фармакопейний центр якості лікарських засобів». Державна Фармакопея України. (2-е вид.). (Доп. 4). Харків: ДП «Український науковий фармакопейний центр якості лікарських засобів». 2020.

17. ДП «Український науковий фармакопейний центр якості лікарських засобів». Державна Фармакопея України. (Т. 1-3). (2-е вид.). Харків: ДП «Український науковий фармакопейний центр якості лікарських засобів». 2015.

18. Настанова СТ-Н МОзУ 42-4.5:2015. Вимоги до виготовлення нестерильних лікарських засобів в умовах аптек. Київ: М03 України. 2015.

19. Мельник Г.М., Ярних Т.Г., Герасимова I.В. Теоретичне обгрунтування вибору активних фармацевтичних інгредієнтів з метою створення засобу для застосування у підготовці до пологів. Украӥнський біофармацевтичний журнал. 2020. № 4(65). P. 24-28. 


\section{References}

1. Jansson, M.H., Franzén, K., Hiyoshi, A. et al (2020) Risk factors for perineal and vaginal tears in primiparous women - the prospective POPRACTcohort study. BMC Pregnancy Childbirth, 20. 749.

2. Merriam, A.A., Ananth, C.V., Wright, J.D., Siddiq Z., D'Alton M.E., Friedman A.M. (2017) Trends in operative vaginal delivery, 2005-2013: a populationbased study. BJOG, 124(9). 1365-1372.

3. Abraham de Jesús-García, Sergio Paredes-Solís, Geovani Valtierra-Gil et al (2018) Associations with perineal trauma during childbirth at home and in health facilities in indigenous municipalities in southern Mexico: a cross-sectional cluster survey. BMC Pregnancy Childbirth, 18. 198.

4. Bodner-Adler, B., Kimberger, O., Griebaum, J., Husslein, P., Bodner, K. (2017) A ten-year study of midwife-led care at an Austrian tertiary care center: a retrospective analysis with special consideration of perineal trauma. BMC Pregnancy Childbirth, 17(1). 357.

5. Ryan Goh Daryl, Goh Hasthika Ellepola (2018) Perineal tears - A review. Australian Journal of General Practice, 47(1-2). 35-38.

6. Vale de Castro Monteiro, M., Pereira, G.M., Aguiar, R.A., Azevedo, R.L. et al (2016) Risk factors for severe obstetric perineal lacerations. Int Urogynecol $J$, 27(1). 61-67.

7. Fodstad, K., Staff, A.C., Laine, K. (2019) Sexual activity and dyspareunia the first year postpartum in relation to degree of perineal trauma. Int Urogynecol J, 27(10). 1513-1523.

8. Sarah, Krezić, Esved, Krhan et al (2019) Fabrication of rectal and vaginal suppositories using 3D printed moulds: the challenge of personalized therapy. IFMBE, 73. 729-734.

9. Michael Barsky, Robert Kelley et al (2018) Customized Pessary Fabrication Using ThreeDimensional Printing Technology. Obstet Gynecol, 131(3). 493-497.

10. Frigerio, M., Manodoro, S., Bernasconi, D. et al (2018) Incidence and risk factors of third- and fourth- degree perineal tears in a single Italian scenario. Eur J Obstet Gynecol Reprod Biol, 221. 139-143.

11. Webb, S., Yates, D., Manresa, M. et al (2017) Impact of subsequent birth and delivery mode for women with previous OASIS: systematic review and meta-analysis. Urogynecol J. 28. 507-514.

12. Ginath, S., Elyashiv, O., Weiner, E., et al (2017) The optimal angle of the mediolateral episiotomy at crowning of the head during labor. Int Urogynecol J, 28(12). 1795-99.

13. Shherbina, N.A. et al (2017) Racional'naja podgotovka rodovyh putej kak metod snizhenija travmatizma mjagkih tkanej v rodah. Reproduktivna endokrinologija, 6(38). 91-95.

14. Melnyk Galyna, Yarnykh Tatyana, Herasymova Iryna (2020) Analytical Review of the Modern Range of Suppository Bases. Sys Rev Pharm, 11(4). 503-508.

15. Liapunov, M., Bezuhla, O., Pidpruzhnykov, Yu. ta in. (2011) ST-N MOZU 42-3.0:2011 Likarski zasoby. Farmatsevtychna systema yakosti (ICH Q8). Kyiv : MOZ Ukrainy.

16. DP «Ukrainskyi naukovyi farmakopeinyi tsentr yakosti likarskykh zasobiv». (2020). Derzhavna Farmakopeia Ukrainy. (2nd ed.). (Suppl. 4). Kharkiv: DP «Ukrainskyi naukovyi farmakopeinyi tsentr yakosti likarskykh zasobiv».

17. DP «Ukrainskyi naukovyi farmakopeinyi tsentr yakosti likarskykh zasobiv». (2015). Derzhavna Farmakopeia Ukrainy. (Vols. 1-3; Vol. 3). (2nd ed.). Kharkiv: DP «Ukrainskyi naukovyi farmakopeinyi tsentr yakosti likarskykh zasobiv».

18. Nastanova ST-N MOZU 42-4.5:2015 (2015) Vymohy do vyhotovlennia nesterylnykh likarskykh zasobiv v umovakh aptek. Kyiv: MOZ Ukrainy.

19. Melnyk, H.M., Yarnykh, T.H., Herasymova, I.V. (2020) Teoretychne obgruntuvannia vyboru aktyvnykh farmatsevtychnykh inhrediientiv z metoiu stvorennia zasobu dlia zastosuvannia u pidhotovtsi do polohiv. Ukrainskyi biofarmatsevtychnyi zhurnal, 4(65). 24-28.

\title{
ЭКСПЕРИМЕНТАЛЬНОЕ ОБОСНОВАНИЕ ВЫБОРА СУППОЗИТОРНОЙ ОСНОВЫ ЭКСТЕМПОРАЛЬНЫХ ПЕССАРИЕВ ДЛЯ ПОДГОТОВКИ К РОДАМ
}

\section{Г.н. Мельник, Т.Г. Ярных, И.В. Герасимова}

\author{
Национальный фармацевтический университет, г. Харьков, Украина
}

Целью работы стало проведение физико-химических и фармако-технологических исследований по выбору рациональной суппозиторной основы при создании экстемпоральных пессариев (вагинальных суппозиториев) с гиалуроновой кислотой и $\mathrm{CO}_{2}$-экстрактами алоэ, календулы и зеленого чая, предназначенных для подготовки родовых путей и уменьшения риска возникновения разрывов мягких тканей при родах.

Материалы и методы. Объектом исследования были образцы пессариев, приготовленные методом выливания с использованием в качестве активных фармацевтических ингредиентов: гиалуроновой кислоты, $\mathrm{CO}_{2}$-экстрактов алоэ, календулы и зеленого чая. Образцы пессариев готовили с использованием 8 качестве суппозиторных основ: витепсол $H-15$, масло какао, твердый жир кондитерский и масло какао в 
сплаве с эмульсионным воском в соотношении 95:5. При исследовании определяли однородность, среднюю массу, $р H$, температуру плавления, время полной деформации, время распадаемости и микробиологическую чистоту пессариев по методикам ГФУ. Биобармацевтические исследования проводили, используя общепринятый метод «агаровых пластин».

Результаты. На основании физико-химических и фармако-технологических исследований выбрано рациональную суппозиторную основу масло какао : эмульсионный воск (95:5). Изучены основные показатели качества образцов пессариев (вагинальных суппозиториев): органолептические характеристики (цвет, поверхность, запах, консистенция), среднюю массу, температуру плавления, время полной деформации, время распадания, $р$, которые соответствуют требованиям ГФУ. В результате определения микробиологической чистоты установлено, что общее число жизнеспособных микроорганизмов (ТАМС) не превышает $10^{2}$ КУО/мл, общее число дрожжевых и плесневых грибов (ТҮМС) не превышает 101. Полученные результаты испытания соответствуют требованиям ГФУ к пессариям по показателю «Микробиологическая чистота». Биофармацевтическими исследованиями доказано, что наибольшая степень высвобождения действующих веществ происходит из пессариев приготовленных на основе масло какао : эмульсионный воск (95:5) по сравнению с образцами, изготовленными на основе витепсола $\mathrm{H}-15$.

Выводы. Проведены физико-химические и фармако-технологические исследования по выбору суппозиторной основы при создании экстемпоральных пессариев (вагинальных суппозиториев) $c$ гиалуроновой кислотой и $\mathrm{CO}_{2}$ экстрактами алоэ, календулы и зеленого чая. Выбрано рациональную основу масло какао : эмульсионный воск (95:5). Изучены физико-химические и фармако-технологические показатели пессариев: однородность, температура плавления, время полной деформации, время распадаемости, $p H$, средняя масса, соответствующие требованиям статьи ГФу 2.0 «Суппозитории и пессарии, приготовленные в условиях аптек».

Ключевые слова. Экстемпоральные пессарии; суппозиторная основа; температура плавления; время полной деформации, время распадаемости, микробиологическая чистота.

\title{
EXPERIMENTAL JUSTIFICATION OF THE CHOICE OF SUPPOSITORY BASE FOR EXTEMPORANEOUS PESSARIES FOR CHILDBIRTH PREPARATION
}

\section{Galyna Melnyk, Tatyana Yarnykh, Iryna Herasymova}

\author{
National University of Pharmacy, Kharkiv, Ukraine
}

The purpose of the work was to conduct physicochemical and pharmaco-technological studies on the choice of a rational suppository base during creation of extemporaneous pessaries (vaginal suppositories) with hyaluronic acid and $\mathrm{CO}_{2}$-extracts of aloe, calendula and green tea, designed to prepare the birth canal and reduce the risk of soft tissue ruptures during childbirth.

Materials and methods. The object of the study was pessary samples prepared by casting method using as active pharmaceutical ingredients: hyaluronic acid, $\mathrm{CO}_{2}$-extracts of aloe, calendula and green tea. Samples of pessaries were prepared by using as suppository bases: Witepsol H-15, cocoa butter, solid confectionery fat and cocoa butter in an alloy with emulsion wax in a ratio of 95:5. During the studies, homogeneity, average weight, $p H$, melting point, time of complete deformation, disintegration time and microbiological purity of pessaries were determined according to SPhU methods. Biopharmaceutical studies were performed using the conventional «agar plate» method.

Results. Based on physicochemical and pharmaco-technological studies, cocoa butter: emulsion wax (95:5) was chosen as a rational suppository base. The main indicators of the quality of samples of pessaries (vaginal suppositories) were studied: organoleptic characteristics (color, surface, odor, consistency), average weight, melting point, time of complete deformation, disintegration time, $p H$, which meet the requirements of the SPhU. As a result of determining the microbiological purity, it was established that the total number of viable microorganisms (TAMC) does not exceed $10^{2} \mathrm{CFU} / \mathrm{ml}$, the total number of yeasts and molds (TYMC) does not exceed 10 ${ }^{1}$. The test results obtained comply with the requirements of the State Pharmacopoeia of Ukraine for pessaries in terms of the indicator "Microbiological purity». Biopharmaceutical studies have shown that the greatest release of active substances occurs from pessaries prepared on cocoa butter: emulsion wax (95:5) compared to samples prepared on the basis of Witepsol $\mathrm{H}-15$.

Conclusions. Physicochemical and pharmaco-technological studies have been carried out on the choice of a suppository base during creation of extemporaneous pessaries (vaginal suppositories) with hyaluronic acid and $\mathrm{CO}_{2}$ extracts of aloe, calendula and green tea. Cocoa butter: emulsion wax (95:5) selected as a rational base. Physicochemical and pharmaco-technological indicators of pessaries were studied: homogeneity, melting point, time of complete deformation, disintegration time, $p H$, average weight, corresponding to the requirements of SPhU 2.0 article «Suppositories and pessaries prepared in a pharmacy».

Keywords. Extemporaneous pessaries; suppository base; melting temperature; complete deformation time, disintegration time, microbiological purity. 
Конфлікт інтересів. Відсутній.

Conflicts of interest: authors have no conflict of interest to declare.

\section{Відомості про авторів:}

Мельник Г.М.А,B,C,D - к. фарм. н., докторант кафедри технології ліків, Національний фармацевтичний університет, м. Харків, Україна.

e-mail: tl@nuph.edu.ua; ORCID: https://orcid.org/0000-0002-4333-2094

Ярних Т.Г. А,E,F - д. фармац. н., професор, завідувач кафедри технології ліків, Національний фармацевтичний університет, м. Харків, Україна.

e-mail: tl@nuph.edu.ua; ORCID: https://orcid.org/0000-0001-8496-1578

Герасимова I.B. в,с,E - к. фармац. н., доцент кафедри технології ліків, Національний фармацевтичний університет, м. Харків, Україна.

e-mail: iryna herasymova@ukr.net; ORCID: https://orcid.org/0000-0003-2794-5541;

$A$ - концепція та дизайн дослідження; $B$ - збір даних; $C$ - аналіз та інтерпретація даних;

$D$ - написання статmi; $E$ - редагування статmi; F - остаточне затвердження статті.

\section{Сведения про авторов:}

Мельник Г.м. - к. фарм. н., докторант кафедры технологии лекарств, Национальный фармацевтический университет, г. Харьков, Украина.

Ярных Т.Г. - д. фармац. н., профессор, заведующая кафедрой технологии лекарств, Национальный фармацевтический университет, г. Харьков, Украина.

Герасимова И.В. - к. фармац. н., доцент кафедры технологии лекарств, Национальный фармацевтический университет, г. Харьков, Украина.

Information about authors:

Melnyk G. M. A,B,C,D - PhD (Pharmacy), postdoctoral student of the Technology of Drugs Department, National University of Pharmacy, Kharkiv, Ukraine.

e-mail: tl@nuph.edu.ua; ORCID: https://orcid.org/0000-0002-4333-2094

Yarnykh Tatyana A,E,F - DSc (Pharmacy), Professor, head of the Technology of Drugs Department, National University of Pharmacy, Kharkiv, Ukraine.

e-mail: tl@nuph.edu.ua; ORCID: https://orcid.org/0000-0001-8496-1578

Herasymova Iryna B,C,E - PhD (Pharmacy), Ass. Prof. of the Technology of Drugs Department, National University of Pharmacy, Kharkiv, Ukraine.

e-mail: iryna herasymova@ukr.net; ORCID: https://orcid.org/0000-0003-2794-5541.

$A$ - research concept and design; $B$ - collection and/or assembly of data; $C$ - data analysis and interpretation;

$D$ - writing the article; $E$ - critical revision of the article; $F$ - final approval of the article.

Адреса для листування: вулиця Пушкінська, 53, Харків, 61000 